\title{
17 \\ ICT, POWER, AND DEVELOPMENTAL DISCOURSE: A CRITICAL ANALYSIS
}

\author{
Mark Thompson \\ Judge Institute of Management \\ University of Cambridge \\ Cambridge \\ United Kingdom
}

\begin{abstract}
This paper uses critical discourse analysis to demonstrate how information and communications technology (ICT) has become deeply involved in the conception and practice of socio-economic development within so-called less-developed countries (LDCs). A recent speech on ICT by the president of the World Bank Group is examined, showing the role of the discourse surrounding such technologies in replicating and extending a markedly North American worldview into the developmental sphere. The ability of critical discourse analysis to expose the involvement of ICT in normalizing a dominant set of political and economic assumptions confirms its usefulness as a tool with which to approach the critical study of information systems.
\end{abstract}

\section{INTRODUCTION: DEVELOPMENT AND ICT AS CONTESTED DOMAINS}

This paper has two aims: to draw attention to the dual role of information and communications technology (ICT) as both the medium and the subject of discursive power relations, and to demonstrate the usefulness to information systems (IS) researchers of an adapted form of critical discourse analysis in identifying and exposing this relationship in their own fields of study. In seeking to achieve these aims, a highly problematic discursive domain has been 
chosen for discussion: the field of development, which, with its almost unique ability to define others, identify their problems, and to legitimize professional intervention in their daily lives, has proved a particularly rewarding subject in the 1990s for critical analysis. The paper is organized simply. The introduction provides a brief summary of why development should, perhaps, be surrounded by quotation marks, together with a short account of the increasing role played by ICT in mediating developmental discourse. The main section then explains critical discourse analysis, shows how it has been adapted here to provide an arguably powerful framework for a critical paper, and then demonstrates this method, through detailed analysis of parts of a recent speech on the subject of ICT by a key proponent of development: the president of the World Bank. Finally, the conclusion provides some reflections on the likely usefulness of such an approach for those seeking to problematize the discursive role of ICT within other domains.

\subsection{The Discourse of Development}

Following Foucault, who defined discourse as "the interplay of the rules that make possible the appearance of objects during a given period of time" (1972, p. 33), various recent critical writers on development have used the theoretical relationship between power and knowledge addressed by discourse analysis to attain "a radical reading of subjectivity in the sense that through discourses individuals become subjects" (Mohan 1997; see also Said 1978). In questioning the legitimacy of the developmental professional gaze (Sachs 1992) to define and thus subjectify recipients of aid, critics of development have highlighted instead the importance of situated, local knowledge as opposed to the representational knowledge of professionals (Chambers et al. 1989; Hobart 1993; Long and Long 1992; Pottier 1993), but stressed that, all too often, it is the latter which, as legitimate discourse, comes to shape developmental interventions (Gardner and Lewis 1996).

Perhaps the most influential contribution to the post-structuralist critique of development has been that of Escobar (1995), whose Foucauldian Encountering Development is an often angry description of the way in which the problematization of poverty and development have coevolved within development discourse. In a clear demonstration of the way in which discourse creates and sustains relations of power, Escobar describes the "discovery" of poverty by the West in the post-war period; the transformation of the poor into the assisted; the associative linking of philanthropy with morality, and poverty with degeneracy; the invention of development as a response to this object; the explicit (latterly implicit) assumption of linear evolution along a Western 
trajectory; the theorization of technology as a sort of moral force, and the growth, professionalization and institutionalization of expertise about the Third World. In Escobar's view:

Development was...the result of the establishment of a set of relations among these elements, institutions, and practices and of the systematization of these relations to form a whole (1995, p. 40).

As a result,

The forms of power that have appeared act not so much by repression but by normalization...the construction of the poor and undeveloped as universal, preconstituted subjects, based on the privilege of the representers (1995, p. 53).

As a set of relations which objectifies and structures marginality and thus arguably reproduces networks of power, development is thus a particularly fitting subject for discourse analysis (Dahl and Hjort 1984).

\subsection{ICT as Mediator and Subject of Developmental Discourse}

There is, moreover, a compelling case for examining the growing part played by ICT in shaping how the discourse of development achieves such a structuring of marginality. This increasingly important involvement occurs on two levels. The first level involves the role of ICT as mediator of developmental discourse; this forms the subject of the remainder of this introductory section. Having gained an awareness of ICT's role as mediator, it is hoped that the reader will then be in a position to appreciate the implications of ICT's second level of involvement in development, which forms the focus of the critical discourse analysis in this paper: as a form of developmental discourse itself.

ICT works to mediate developmental discourse at both macro- and microlevels. At the macro-level, ICT is structurally integrating communities into wider, uneven networks of power. Although usually remaining on the periphery of flows of knowledge and wealth, less-developed countries (LDCs) are nonetheless integrated involuntarily within global networks of capital, production, trade, and communication, increasingly mediated by ICT (Castells 1997, 1998). This recognition has resulted in the inclusion of such technologies as important elements of developmental strategies and interventions (e.g. Gillespie and 
Cornford 1997; UNCTAD 1997; UNESCO 1996), and unprecedented levels of investment in ICT by major developmental donors, often at the expense of alternative forms of initiative (Jensen [2001] provides a useful summary of some recent investment figures). The discourse surrounding the appropriate use of ICT in LDCs is thus becoming part of developmental discourse itself, as macrolevel developmental policy options are becoming increasingly linked to the shape of technological evolution (Perez 1988).

At the micro-level, the power relations surrounding the development and use of ICT in developmental contexts are more ubiquitous. In the words of Bloomfield and Coombs (1992):

information system embodies a particular view or model of the world...thus in contrast to the earlier views of computers and power, we must shift our focus...to consider the meaning of information systems, the visibilities... whose creation and mobilization they make possible within organizations... and thus their role in classifying, ordering, and constructing reality (1992, p. 467, emphasis in original).

Rather than being inherently top-down in nature, the operation of power within ICTs in the above sense lies in their mediation of the contested domain of what becomes visible and real. Within the developmental environment, this entails an especial danger, since

The computer evolved overwhelmingly in the West in a manner compatible with Western mentality, cultural and political values. When IT is injected into cultures such as those of North Africa, it comes loaded with an embedded virtual value system (Danowitz et al. 1995, p. 28).

Although in any emergent worldview, "technology is the machine's relationship with its users" (Grint and Woolgar 1997, p. 92), and thus there can be nothing essentialist about the nature of this relationship (see, for example, the variety of examples of such relationships established within LDC contexts in Avgerou and Walsham 2000), there is nonetheless a danger that in its role in mediating what, and how, aspects of development become visible, the frozen discourse of ICT may assist in replicating a wider discourse of marginalization unless there is real sensitivity to the ICT-user relationship within LDC contexts (Avgerou 2000; Bhatnagar 2000; Smithson and Land 1986). Perhaps the most controversial current example of the ability of ICT to mediate developmental discourse is the World Bank's Global Development Gateway (www. 
developmentgateway.org) launched in 2001. As a high-budget ( $\$ 7$ million), high-profile project with further substantial funds already earmarked (Aslam 2001), the Gateway Foundation appears to be independent (as exemplified by its independent website address), yet is in fact funded and controlled by the Bank itself. The Gateway has been extensively criticized (Wilks 2001) for its attempts to normalize the entire developmental field according to the discursive categories of the Bank, its donors, and contractors.

The result has been a policy of non-cooperation with the Gateway by a growing number of developmental stakeholders. As an example, the South African Non-governmental Organization Network, Congress of South African Trade Unions, and South African Non-Governmental Coalition issued a statement in 2001 that they "firmly and unequivocally" declined to participate, claiming:

While the Development Gateway purports to promote local community organizations and their information initiatives, its true intention is to control the development information discourse to promote its own particular perspectives" (Aslam 2001).

Such critics argue that the World Bank's attempt to harness ICT to present one, neutralized, reality of development is crowding out, unfairly competing with, and thus defunding the alternative realities of others, who reject their objectified, or alternative status vis-à-vis the mainstream (Said 1978); in any event, the Gateway is a powerful example of the increasingly perceived importance of ICT in mediating developmental power relations. In seeking to demonstrate how the discourse leading to such initiatives is legitimized and replicated in practice, the approach chosen has thus been a critical analysis of sections of a recent speech on ICT and development given by the Bank's president.

\section{CRITICAL DISCOURSE ANALYSIS OF A SPEECH ON ICT BY THE PRESIDENT OF THE WORLD BANK}

In the previous section, it was explained how ICT acts at both macro- and micro-levels to mediate relations of power in developmental discourse. As befits a critical standpoint, therefore, the structural motivations of the author regarding the proposed discourse analysis have first been explained to the reader. It is hoped as a result that the examples below of the replication of such discourse in practice at the micro-level, where ICT becomes a strand of developmental discourse itself, will emerge clearly to the reader. 


\subsection{Methodology}

The methodology adapted for the purposes of this paper is Fairclough's critical discourse analysis, or CDA (Fairclough 1995a, 1995b, 1999), which locates social structures within a dialectical relationship with social activities. Politically, therefore (addressing the critical part of the method), "connections between the use of language and the exercise of power are often not clear to people, yet appear on closer examination to be vitally important to the workings of power" (Fairclough 1995b, p. 54), while methodologically (addressing the discourse analysis part of the method), "texts constitute a major source of evidence for grounding claims about social structures, relations, and processes" (Fairclough 1995a, p. 209). In fusing power with semiotic activity (a wider category than straight linguistics), CDA views texts as examples of wider discourses, thus blending the approaches to discourse of social theorists such as Foucault (1972) with linguists such as van Dijk (1985). In doing so, CDA differs from purely linguistic approaches to discourse analysis which might, for example, focus in the first instance on constructions such as phonology, morphology, syntax, semantics, and pragmatics (van Dijk 1988).

As might be expected of a critical approach to discourse, CDA seeks to link texts at a micro-level (the textual level) with macro-level power structures (sociocultural practice) which, in drawing upon discourse, such texts reproduce. In CDA, discursive practice is thus the mediator between the macro- and microlevels, as shown in Figure 1.

The activities in bold on the right of the model represent the framework of analysis, in which a piece of text is described, and then the discursive practices upon which it draws are identified, and linked to the underlying power relations which may be reproduced by the interaction. In selecting pieces of text, CDA draws on Bakhtin's concept of utterance (Bakhtin 1981 in Holland et al. 1998, p. 173), a temporarily performed and unique configuration of context, subject positions, and meaning between interacting, dialogical people-although, as Goffman $(1981$, p. 38) has pointed out, audiences for political speeches are usually preratified and thus more favorable reactions may be expected by the speaker (this may explain the use of confidence as a speech genre, as will be seen below).

In selecting sections of a speech for analysis, the analyst therefore looks for identifiable configurations of discursive practice (references 1 through 16 in the text) consisting of discrete, unique utterances, or combinations of idioms, references, inferences or phrases within a particular order of discourse, such as development. In identifying these configurations, Fairclough (1995a) further distinguishes between generic "speech genres," or linguistic devices, that apply horizontally across various orders of discourse (which any researcher, for example, might be likely to find when performing CDA in other domains), and, 


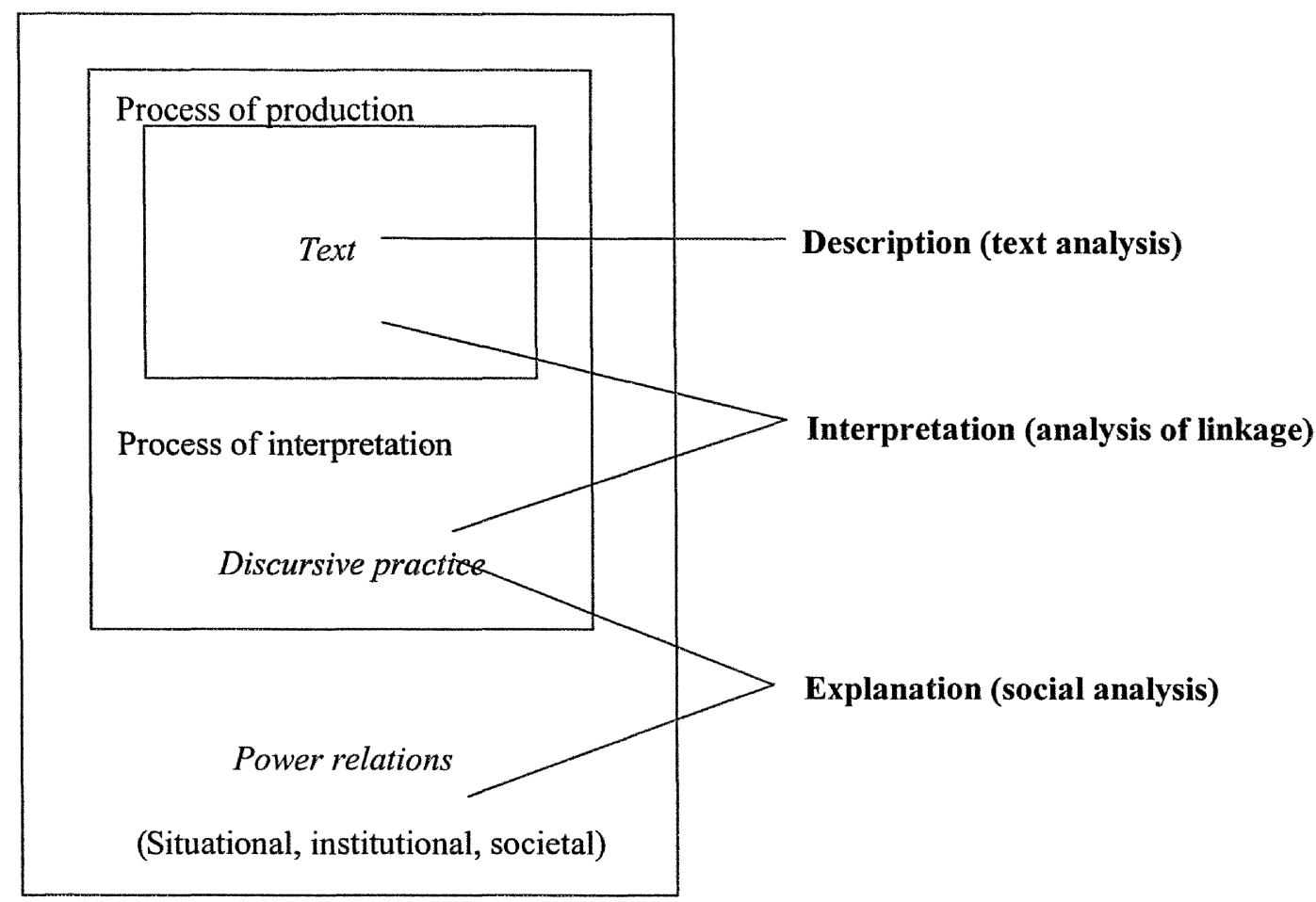

Figure 1. Dimensions of Discourse Analysis (Adapted from Titscher et al. 2000)

\begin{tabular}{|l|l|}
\hline Speech Genre (SG) & Discursive Type (DT) \\
\hline 1 Confidence & 1 Technocracy \\
2 Factual information & 2 Legitimacy \\
3 Humor & 3 Neutrality \\
4 Persuasion & 4 Corporatism \\
& 5 Tech(nological) optimism \\
& 6 Pragmatism \\
aplease note that this term is used in the sense of "something confided" \\
between people.
\end{tabular}

Figure 2 Speech Genres and Discursive Types Identified in this Analysis

by contrast, "discursive types," or themes, formations which are vertically identifiable as part a particular order of discourse and which are likely to remain specific to a particular domain of study. By way of illustration, although all of the categories listed in Figure 2 derive directly from the text, all of the speech genres are common components of everyday conversation, whilst the discursive types listed are likely to be familiar to most interpretive IS researchers. As will 
be seen in the analysis, it is the mixing of (often contradictory) speech genres and discursive types that provides units of discursive practice, and hence discourse, with its unique power.

In the analysis which follows, genres and discursive types were identified from the text using a semi-grounded approach, where data was separated into first- and second-order concepts (Orlikowski 1993; Van Maanen and Barley). Thus recurrent devices and themes were first identified, then reduced upon repeated readings to the higher-level concepts shown in Figure 2. It should be acknowledged that, in common with all semi-grounded approaches involving the identification and distillation of recurrent themes, this exercise inevitably involves subjective judgements on the part of the researcher performing this activity and, as a result, there can be no definitive analysis of a piece of discourse.

However, the inevitably subjective nature of such judgements is offset to some degree by the tabular format in which the analysis of the text has been presented, which represents a departure from previous applications of CDA. In addition to reasons of clarity, the intention of this format is to place both author and reader in exactly the same position to interpret the text, thus actively supporting the development of independent judgements concerning the analysis (although it should be admitted that the author actually attended the speech). Thus a direct link can be traced from the source material (text column), through the initial identification of units of discursive analysis (ref column) and description of these (description column), to the derivation of speech genres and discursive types (interpretation column), through to the macro-level power relations which, it is proposed, are replicated or altered as a result (the explanation column). This format thus has the almost unique advantage within interpretive social enquiry of presenting the reader of a paper with a complete set of all of the analytical materials that were originally at the disposal of the author.

\subsection{Analysis}

The source text for the critical discourse analysis below, of which approximately 50 percent has been selected, was given by James D. Wolfensohn, President of the World Bank Group, to an audience of both academics and nonacademics at Cambridge University on June 24, 2000. It is entitled "New Possibilities in Information Technology and Knowledge for Development in a Global Economy" and is available on the Web (http://www.worldbank.org/html/extdr/ extme/jdwsp062400.htm). Readers are encouraged, if possible, to view the text in its entirety, in order to place the selections below within their proper context. The analysis of selected units of discursive practice is divided into four sections 
reflecting the structure of the speech, which I have termed Introduction, Role of ICT, Initiatives, and Initiatives and Conclusion. Each section of analysis is supported by a corresponding section of commentary.

It is suggested that the reader approach the analysis of the speech section by section, first reading the text column in the table, then the short narrative commentary which follows over the page, followed by a return to the analysis columns of the table, before proceeding to the next part of the text.

\subsubsection{Introduction}

In their analysis of a political speech by a Spanish Secretary of the Interior legitimating the expulsion of African illegal migrants, Rojo and van Dijk argue:

The crucial element in most forms of social and political legitimation is that a powerful group or institution...seeks normative approval for its policies or actions....In such legitimating discourse, institutional actions and policies are typically described as beneficial for the group or society as a whole (1997, p. 528).

Whether or not this is intended by the speaker (this knowledge is, of course, not available to either author or reader), the introductory part of the speech establishes, or replicates, the legitimacy of the position of the World Bank as an (implied) leader within development, a position which will be required as a platform for the legitimation of a particular view of ICT later on. Recalling Escobar's comments earlier regarding the co-emergence in discourse of poverty and development, we can see the rapid establishment of a set of normative relations between these two key elements of developmental discourse. Hence the link column of the analysis shows the emergence of legitimacy (the appeal in Ref 4 to a higher order need for intervention), and technocracy (the assertion of expertise in Ref 1). These two discursive types can be seen as core components of the wider order of discourse underpinning, or replicating, the Bank's position in development. Rojo and van Dijk continue:

If successful, legitimation not only implies the endorsement of specific actions, but usually also extends to the dominant group or institutions themselves, as well as to their position and leadership. This means that legitimation has both a top-down and bottom-up direction (1997, p. 528). 


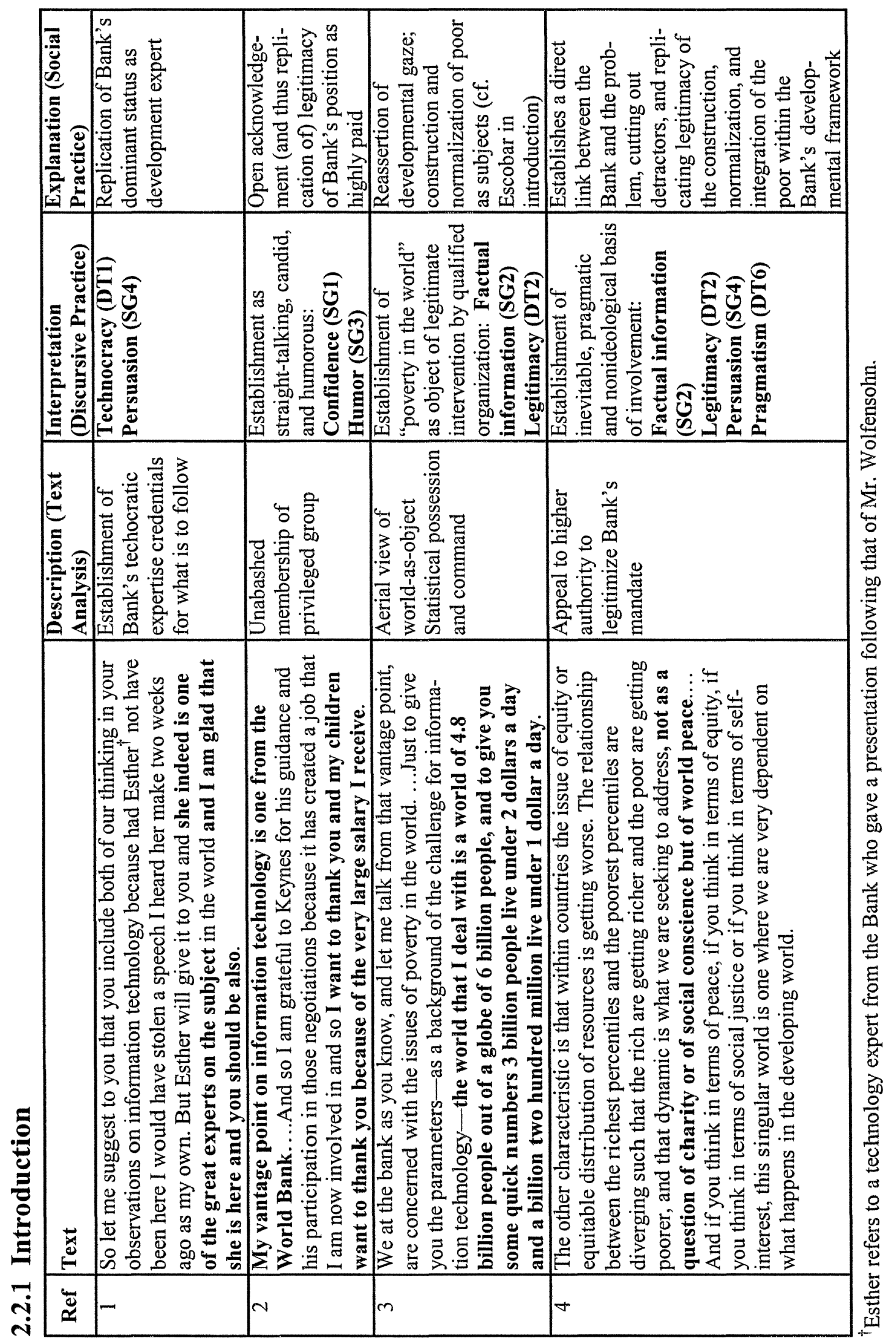


From the above perspective, it appears that in the introductory section of the speech, the speaker has, consciously or unconsciously, legitimated and replicated certain macro-level power relations in practice. As the macro (explanation) column of the analysis shows, the Bank has first reestablished its status as expert (Ref 1); and has then reaffirmed its legitimacy to be paid highly for this (Ref 2). Interestingly, however, Ref 2 is probably the point at which the speaker is most exposed, since he is unabashedly asserting claim to be paid highly in comparison to the development's subjects - some of whom, we later learn, exist on "under 1 dollar a day." Critical discourse analysis offers an explanation for the way in which this uncomfortable power relation is normalized in practice: the reassertion of an unpalatable (and fundamental) aspect of development is mixed with the speech genres of confidence, in which he appears to be confiding in, and thus inviting a personal, co-conspiratorial link with, his audience; and humor, in which the assertion is made in deliberately unacceptable terms, thus undermining serious objection.

By the beginning of Ref 3, the Bank appears precariously poised as a group of highly-paid experts with no object for their expertise, so the poor are quickly introduced (Ref 3) and normalized within the Bank's development paradigm, in which we first hear that ICTs are to play a major part. The two fundamental components of development discourse, the discursive types of technocracy and legitimacy, have now been established, but there remains one further important task: to place this newly established discourse (and hence newly replicated power structure) beyond the realm of questioning. In Ref 4, therefore, we hear not only that the problem is growing worse but that the Bank's intervention has a higher authority than "charity" or "social conscience" (whose underpinnings are, of course, ideological and thus open to question) but "world peace" itself. By the end of this section, the Bank is thus established as almost synonymous with development, and fundamental to the future of our world.

\subsubsection{Role of ICT}

Having reconstituted in the first section of his speech, the core elements of the discursive order upon which the hegemony of the World Bank rests, the speaker then builds, consciously or unconsciously, on this normative platform to outline, at a conceptual level, the Bank's underlying approach to ICT. However, before he is able to introduce this new, potentially disruptive, element into this newly established set of relations, it has to be neutralized and allocated its place within this set as an instrument of, rather than a threat to, Bank policy. Rather than attempt this directly (which would consciously highlight the potential contradiction in the minds of the audience), another, non-ICT-related, threat, Sen's Development as Freedom, is introduced and discussed in detail 


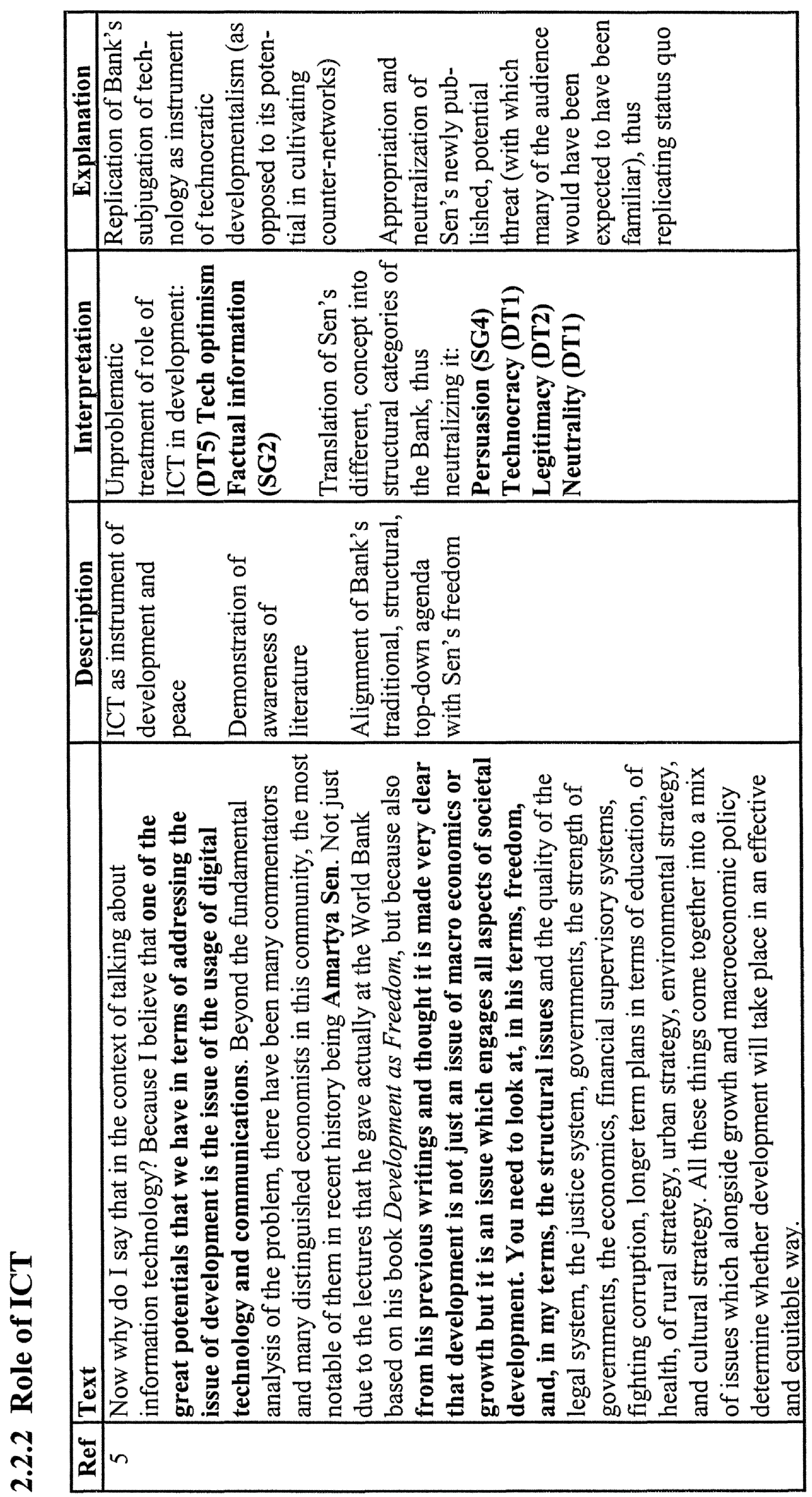




\begin{tabular}{|c|c|c|}
\hline & 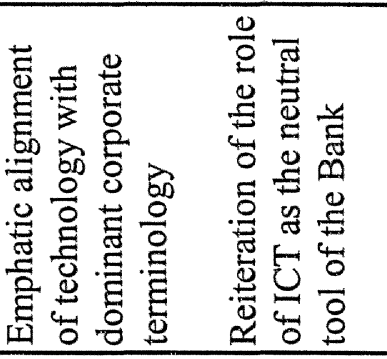 & 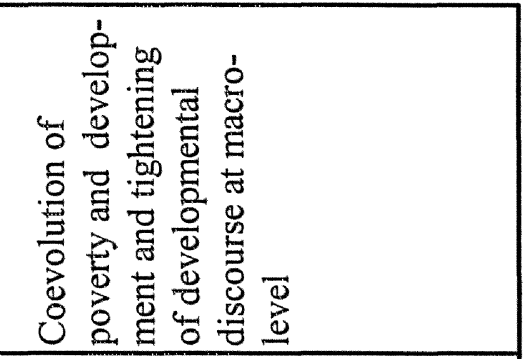 \\
\hline \multicolumn{3}{|c|}{ 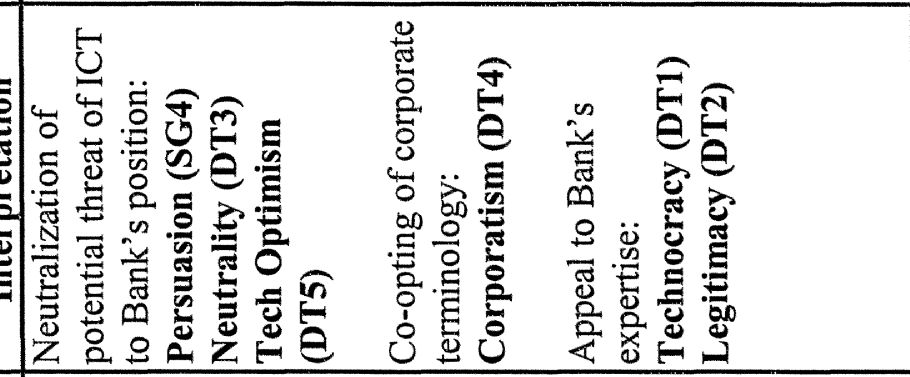 } \\
\hline & 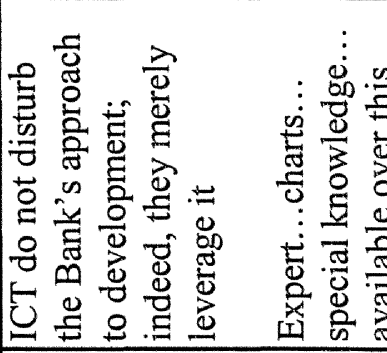 & 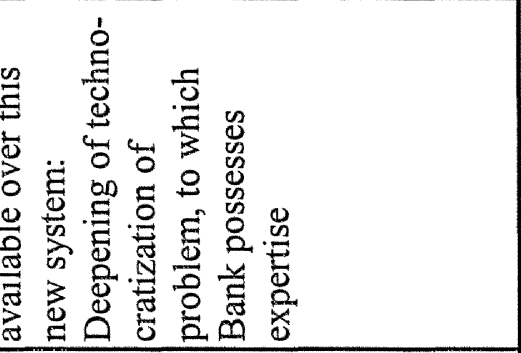 \\
\hline & 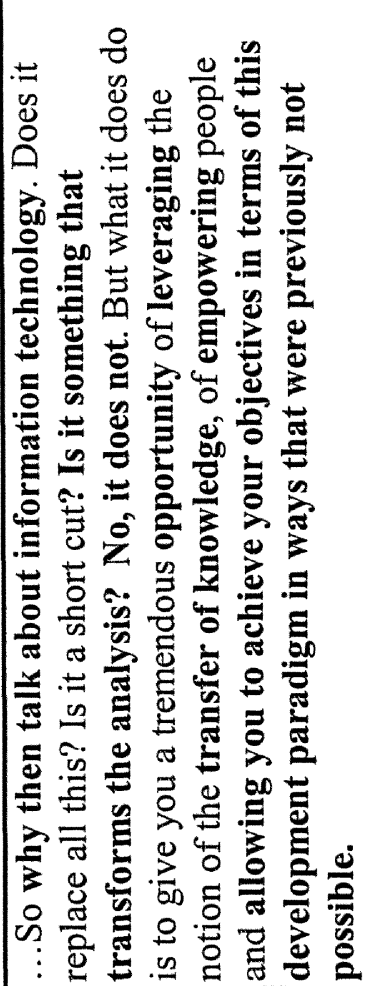 & 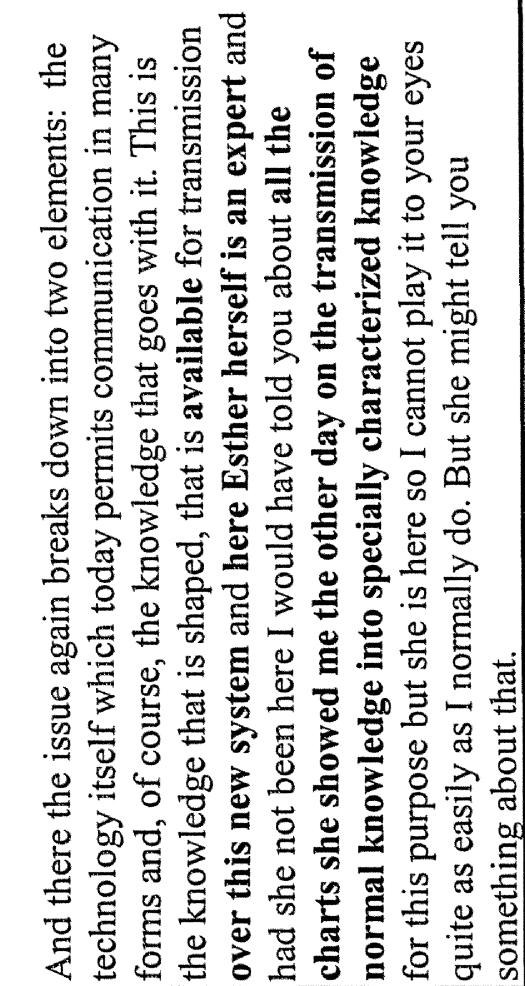 \\
\hline & & \\
\hline
\end{tabular}


(Ref 5), neutralized, and then linked to ICT in Ref 6 (inference: ICT are also nonthreatening) in a technique which has been referred to as masking ( $\mathrm{Ng}$ and Bradac 1993).

In the preface to Development as Freedom, Sen pays tribute to the speaker, "whose vision, skill, and humanity I much admire" (often a preface for criticism), before stating:

The World Bank has not invariably been my favorite organization. The power to do good goes almost always with the possibility to do the opposite, and as a professional economist, I have had occasions in the past to wonder whether the Bank could not have done very much better. These reservations and criticisms are in print $(1999$, p. xiii).

Moreover, almost in anticipation of others' future attempts to represent or normalize his work, Sen continues later in the same page:

...this work is presented mainly for open deliberation and critical scrutiny. I have, throughout my life, avoided giving advice to the "authorities." Indeed, I have never counseled any government, preferring to place my suggestions and critiques ...in the public domain (1999, pp. xiii-xiv).

In the attempt to neutralize the, in many ways, alternative developmental paradigm outlined in Sen's book, Sen is first linked to the World Bank (Ref 5) in a way that, from his above comments, he might surely have disapproved, and his ideas are represented as synonymous with Bank policy:

Not just due to the lectures that he gave actually at the World Bank based on his book Development as Freedom but also from his previous writings....You need to look at, in his terms, freedom, and, in my terms, the structural issues (Text, Ref 5).

By Ref 6, having attacked a less immediately relevant threat, the potential threat of ICT to the Bank's normative position is confronted rhetorically, i.e., from a position of consensual, dominant discourse (first sentence). But is the Bank making appropriate use of ICT? The Bank's expertise and mastery of ICT as a developmental tool remains to be established as a platform for later parts of the speech. In Ref 6, therefore, the speaker invokes a variety of discursive types (components of the development order of discourse) to show that this is the case. To the existing discursive types of technocracy, legitimacy, and pragmatism, 
deployed in the Introduction, are added technological optimism, (the nonnproblematic linking of ICT to opportunity), and corporatism (the deployment, hence ownership of elements of dominant corporate discourse, such as "leveraging," "empowering," "objectives," and "knowledge"). We learn that "normal knowledge" is transmitted, mysteriously, into "specially characterized knowledge" and that, fortunately, we can rely on the World Bank for this.

\subsubsection{Initiatives}

Whether through unconscious habit or rhetorical mastery, by Ref 7, the speaker is now established in a strong position from which to discuss the Bank's ICT-related initiatives. Not only has he reconstituted the essential components of developmental discourse (recalling Escobar once again) and placed this relationship beyond ideological questioning by appealing to a higher legitimacy, but he appears successfully to have neutralized two independent, potential threats by representing them as integral components of the Bank itself. Finally, he has reminded us of the Bank's expert status in wielding one of these tamed threats, ICT, thus tightening its hegemonic control over those requiring "technologizing." A great deal of macro-level structure has thus already been drawn on (in discursive types) and replicated in the discursive order in a fairly short micro-level textual space.

In Ref 7, there is another interesting blending: the speech genre of confidence (an appeal, person-to-person, to the self-evidence of the Internet's potential, even to someone who "grew up without any facility for using Internet") with the harder discursive type of technocracy, which accompanies the announcement of his intention to use ICT to turn his organization into a knowledge bank (the Development Gateway was under construction at the time of this speech). A dramatic expansion of the Bank's mandate (recalling the discussion in the previous section) is thus presented unproblematically at the self-evident level of common sense. This theme is taken up again in Ref 10, where the Gateway itself is introduced at a generic level. Here, however, in contrast to the majority of the speech to date, the pronoun we is employed three times in the first two sentences to create an impression of consensualism using a common device:

...the way in which selectional choices made at the level of definite descriptions may manipulate the hearer's identifications by directing attention away from designated individuals towards some generic role or conceptual category (Wilson 1990, p. 77). 


\begin{tabular}{|c|c|c|c|}
\hline & 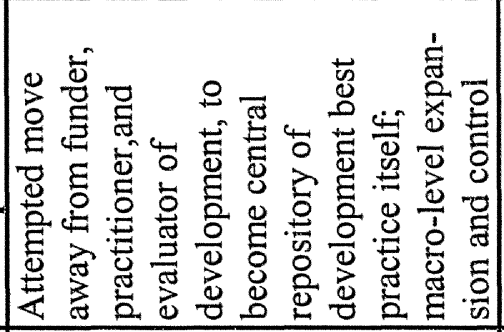 & 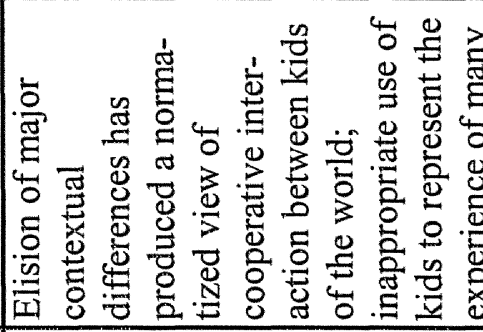 & 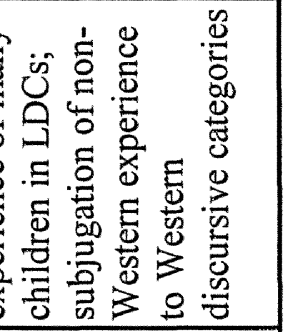 \\
\hline & 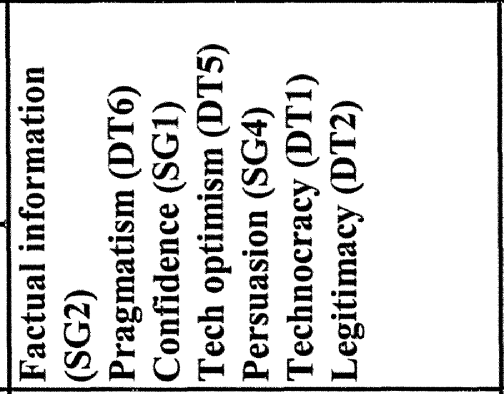 & 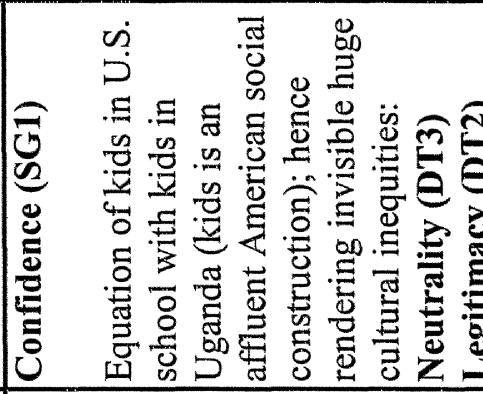 & 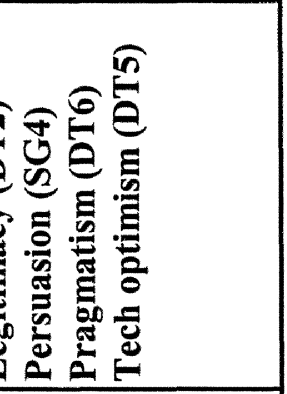 \\
\hline صَّ & 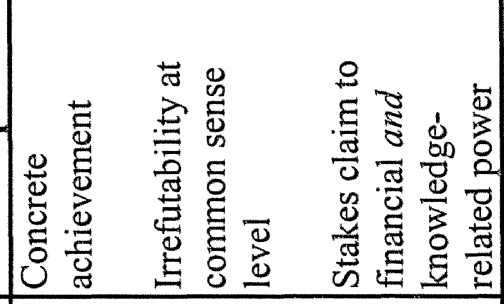 & 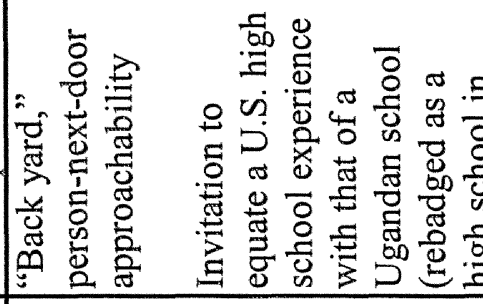 & 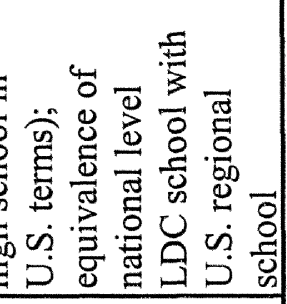 \\
\hline$\stackrel{\vec{d}}{\stackrel{t}{e}}$ & 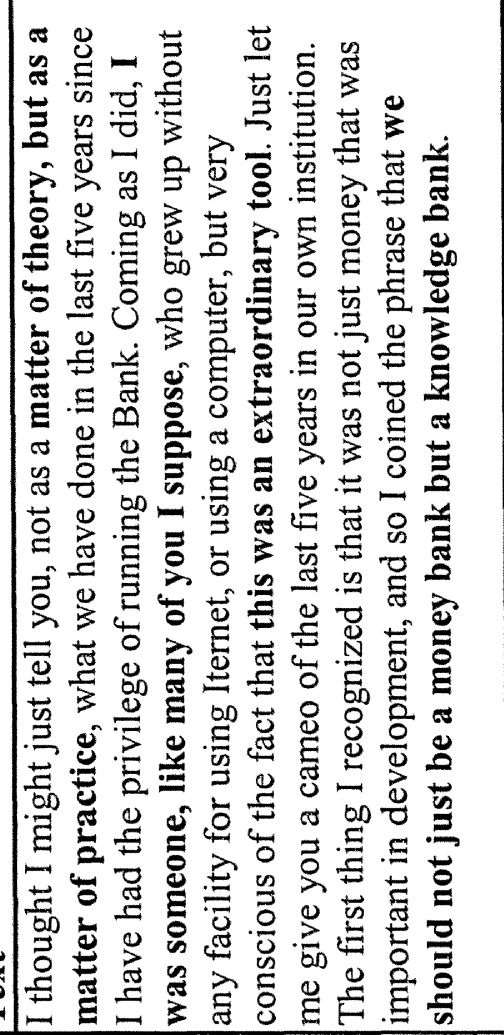 & 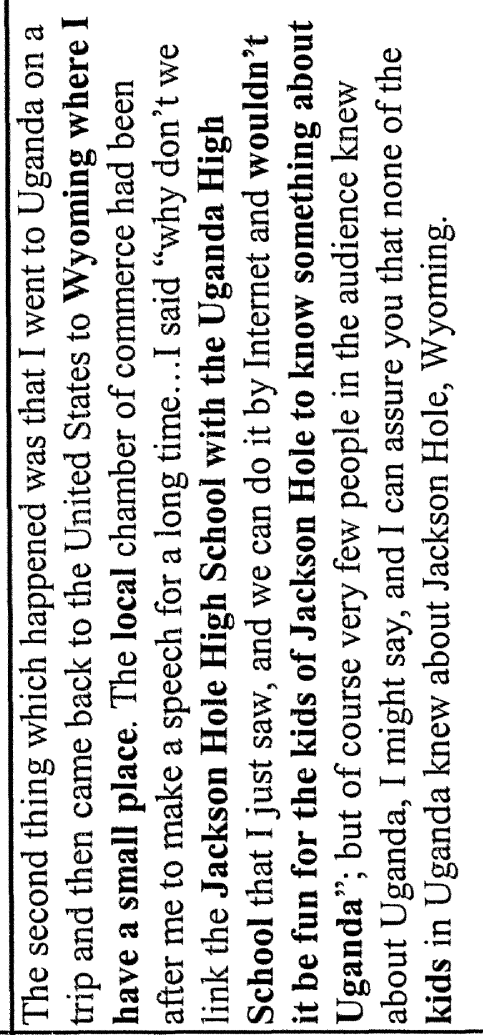 & 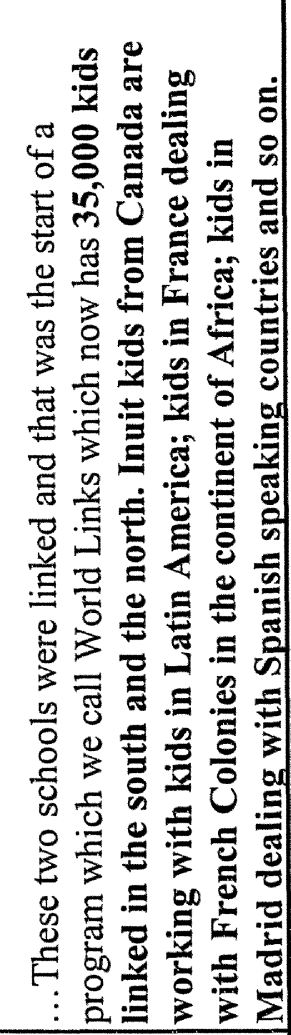 \\
\hline & & & \\
\hline
\end{tabular}




\begin{tabular}{|c|c|c|}
\hline & 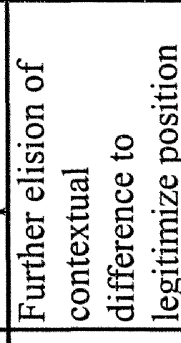 & 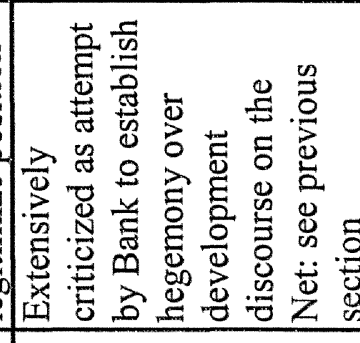 \\
\hline & 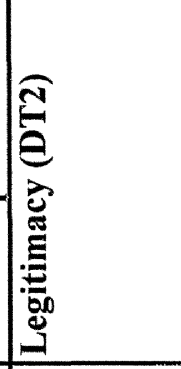 & 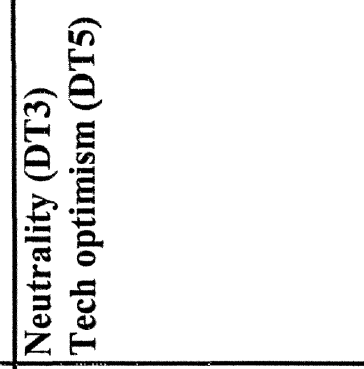 \\
\hline & 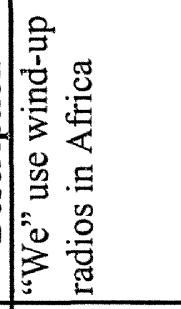 & 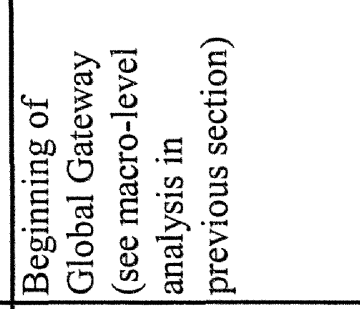 \\
\hline & 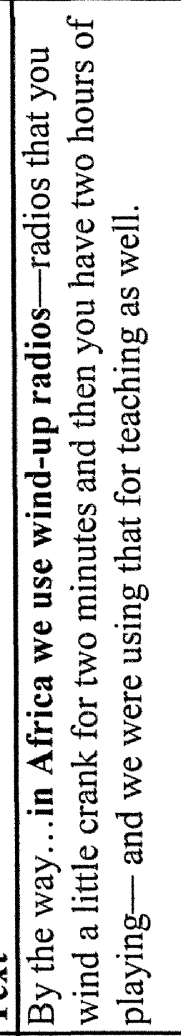 & 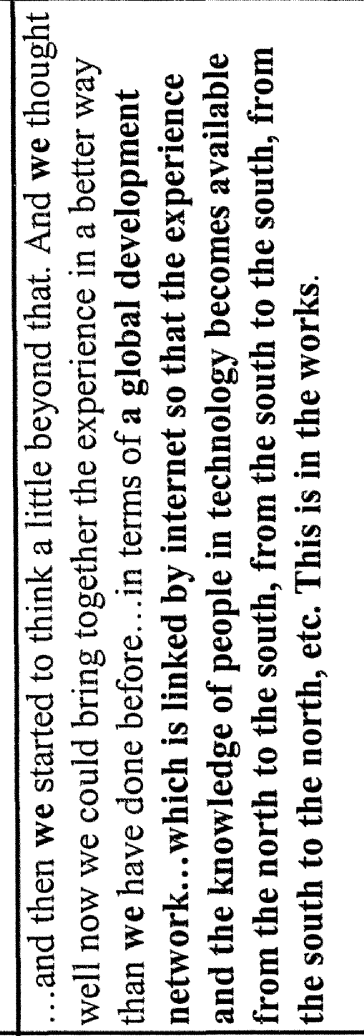 \\
\hline & & \\
\hline
\end{tabular}


However, it is arguable that the most blatant example of the inappropriate use of the collective pronoun within the speech appears at Ref 9, where the speaker comments: “...in Africa, we use wind-up radios" (emphasis added). This comment illustrates a more important point than the simple absurdity of the President of the World Bank Group using wind-up radios in Africa: the tendency of dominant discourse to define, yet assimilate and normalize, otherness, downplaying often major differences in socio-economic and cultural experience.

If the above examples show a localized tendency to normalize, Ref 8 is an example of the use of a normalized Western cultural framework to plan and use ICT within a developmental context. Again, there is an attempt to elide major differences in experience, in which kids link up for "fun" across the world:

...Wouldn't it be fun for the kids of Jackson Hole to know something about Uganda...I can assure you that none of the kids in Uganda knew about Jackson Hole....35,000 kids linked in the south and the north...Inuit kids from Canada are working with kids in Latin America; kids in France...kids in Madrid... and so on $(\operatorname{Ref} 8)$.

It is arguable that the repetition of the word kids throughout the passage is an attempt at appealing to the audience via, in the view of the speaker, a universal, neutral category; however, kids remains a North American cultural construction, not a universal state that accords with the experiences of many children in LDCs, many of whom combine education with an economic role from nearinfancy. Given his position, the speaker's possible unawareness of his cultural bias is possibly of greater concern than the possibility that he was aware, but chose to manipulate it.

\subsubsection{Initiatives and Conclusion}

In contrast to the evidence, presented in the Initiatives part of the speech, of the planning and deployment of ICT in LDCs within frameworks defined by Western (North American) discourse, there is evidence in Refs 11, 12, and 13 of the direct use of ICT to extend the power relations underpinning such discourse. This has already been demonstrated at the macro-level in the previous section, in the discussion of the Development Gateway; as in the analyses of previous parts of the text, the object of interest here is rather the way in which such structures are drawn upon, justified, and hence replicated at the micro-level of the text. 


\begin{tabular}{|c|c|c|c|}
\hline & 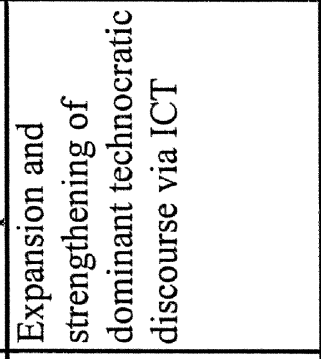 & 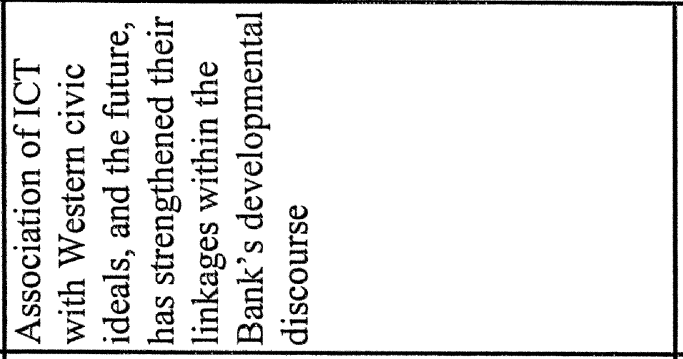 & 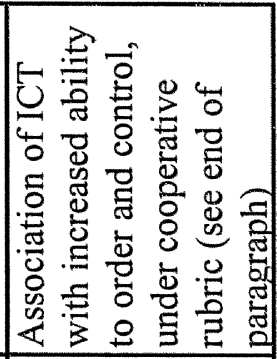 \\
\hline & 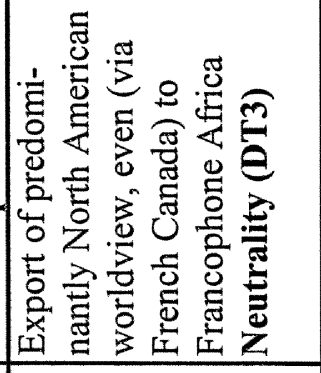 & 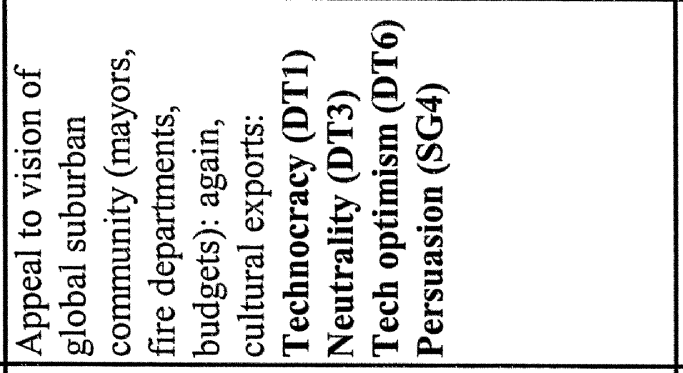 & 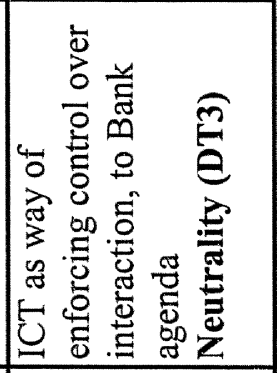 \\
\hline 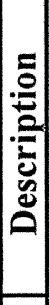 & 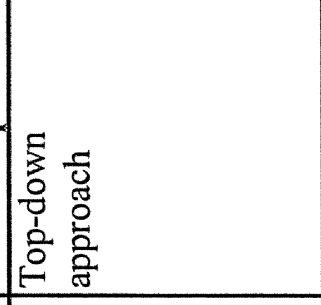 & 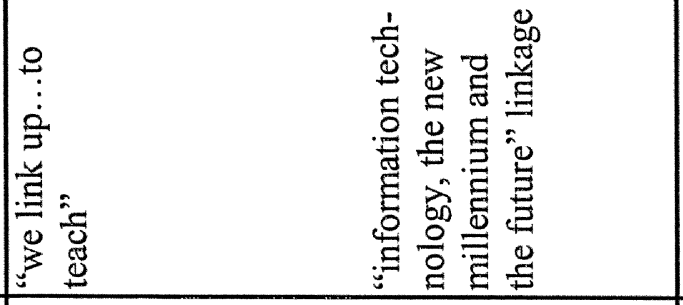 & 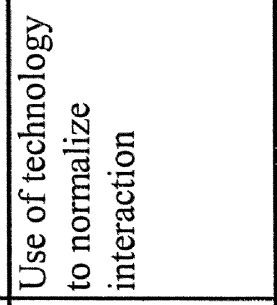 \\
\hline $\begin{array}{l}\vec{t} \\
\stackrel{0}{0}\end{array}$ & 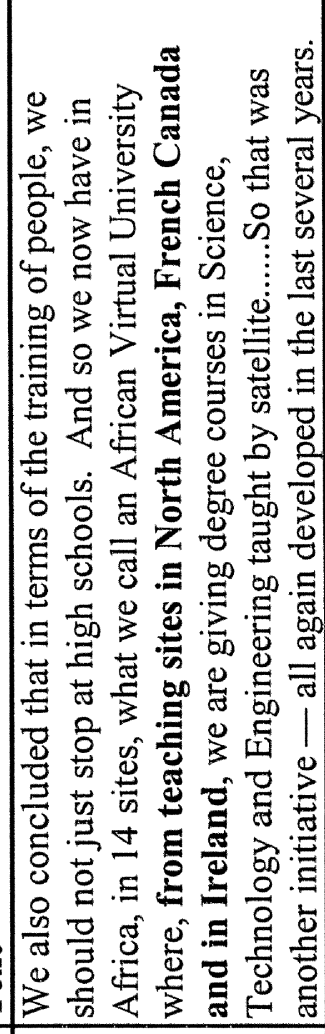 & 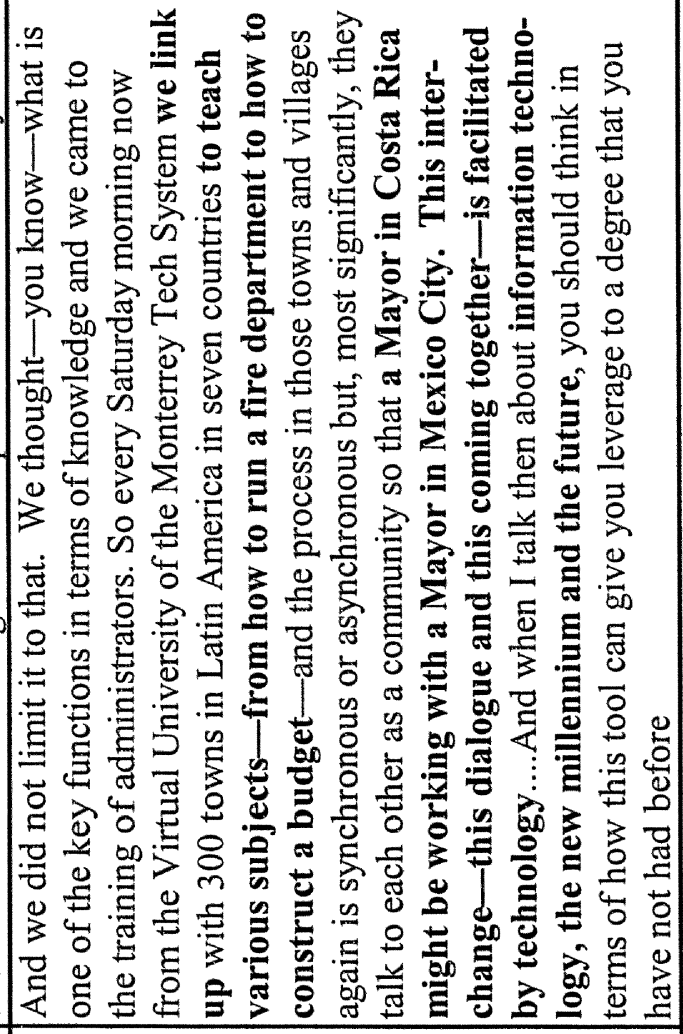 & 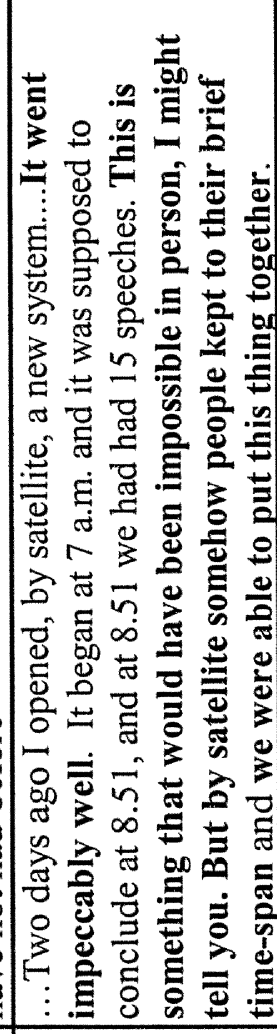 \\
\hline$\stackrel{4}{\simeq}$ & $=$ & $\cong$ & \\
\hline
\end{tabular}




\begin{tabular}{|c|c|c|}
\hline & 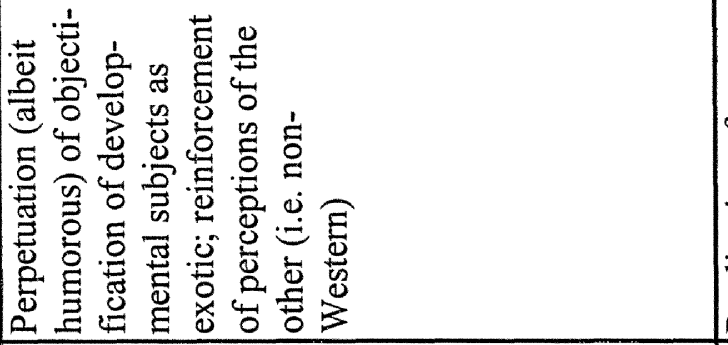 & 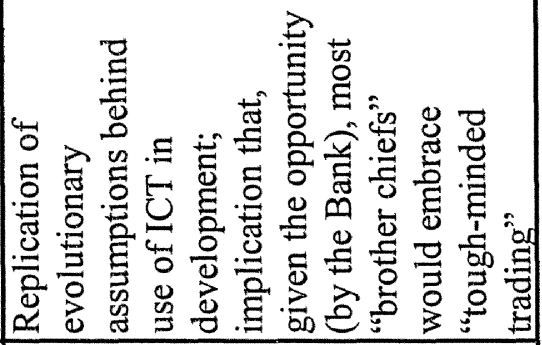 \\
\hline & 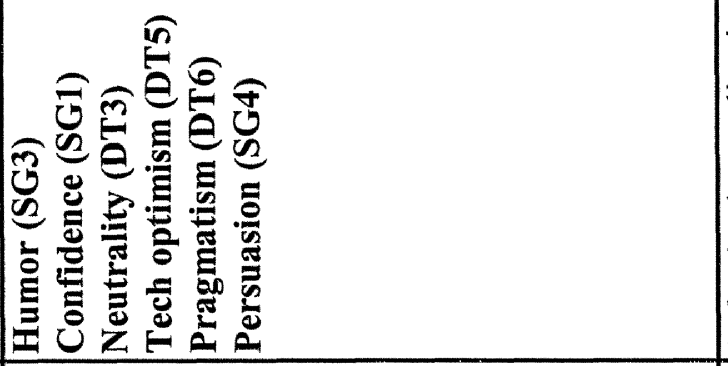 & 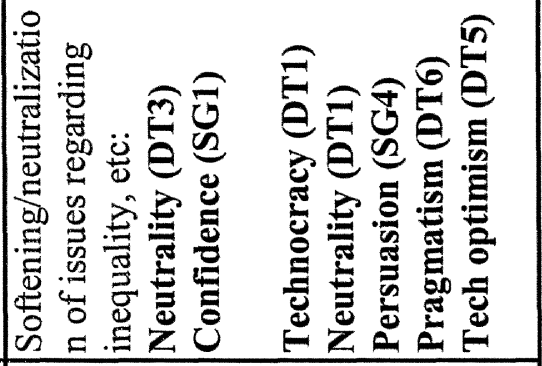 \\
\hline & 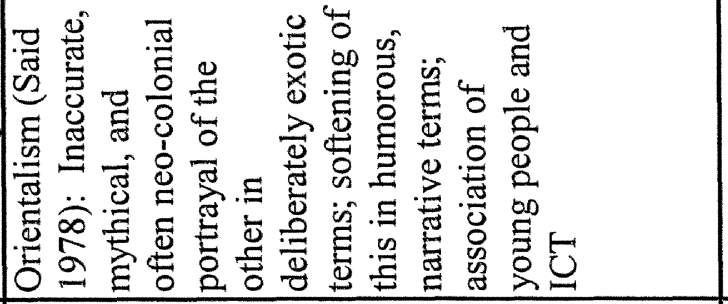 & 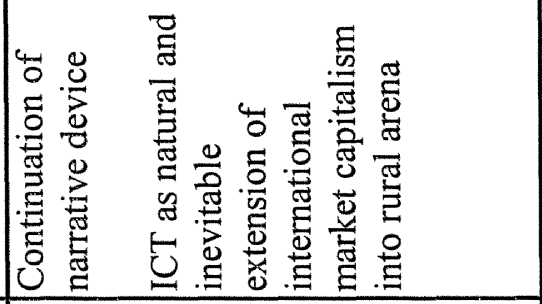 \\
\hline$\stackrel{\vec{e}}{e}$ & 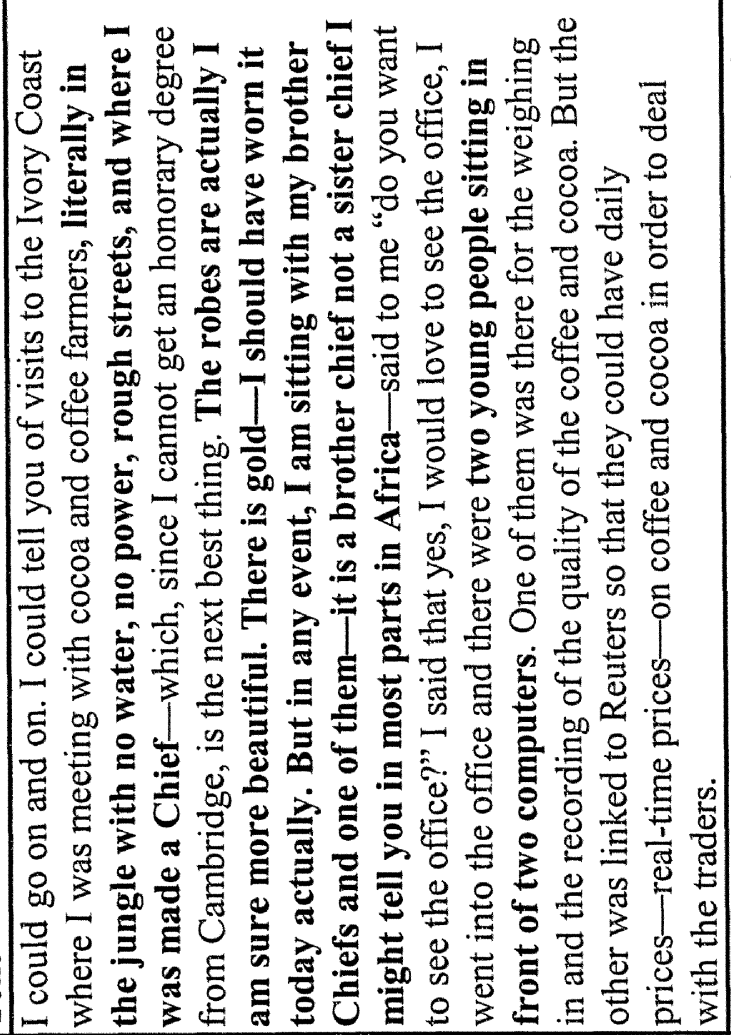 & 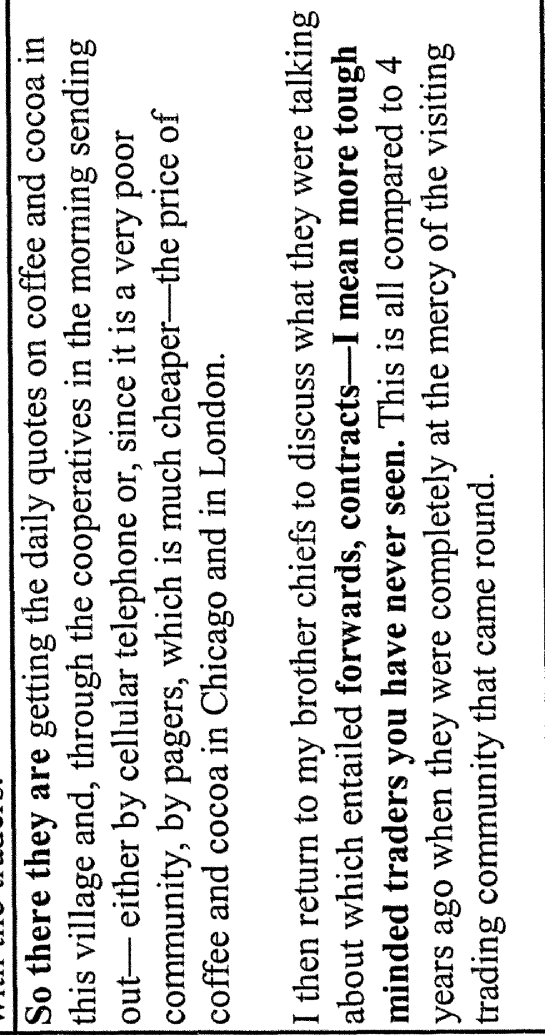 \\
\hline$\stackrel{\mathscr{e}}{\mathscr{e}}$ & \pm & $\cong$ \\
\hline
\end{tabular}




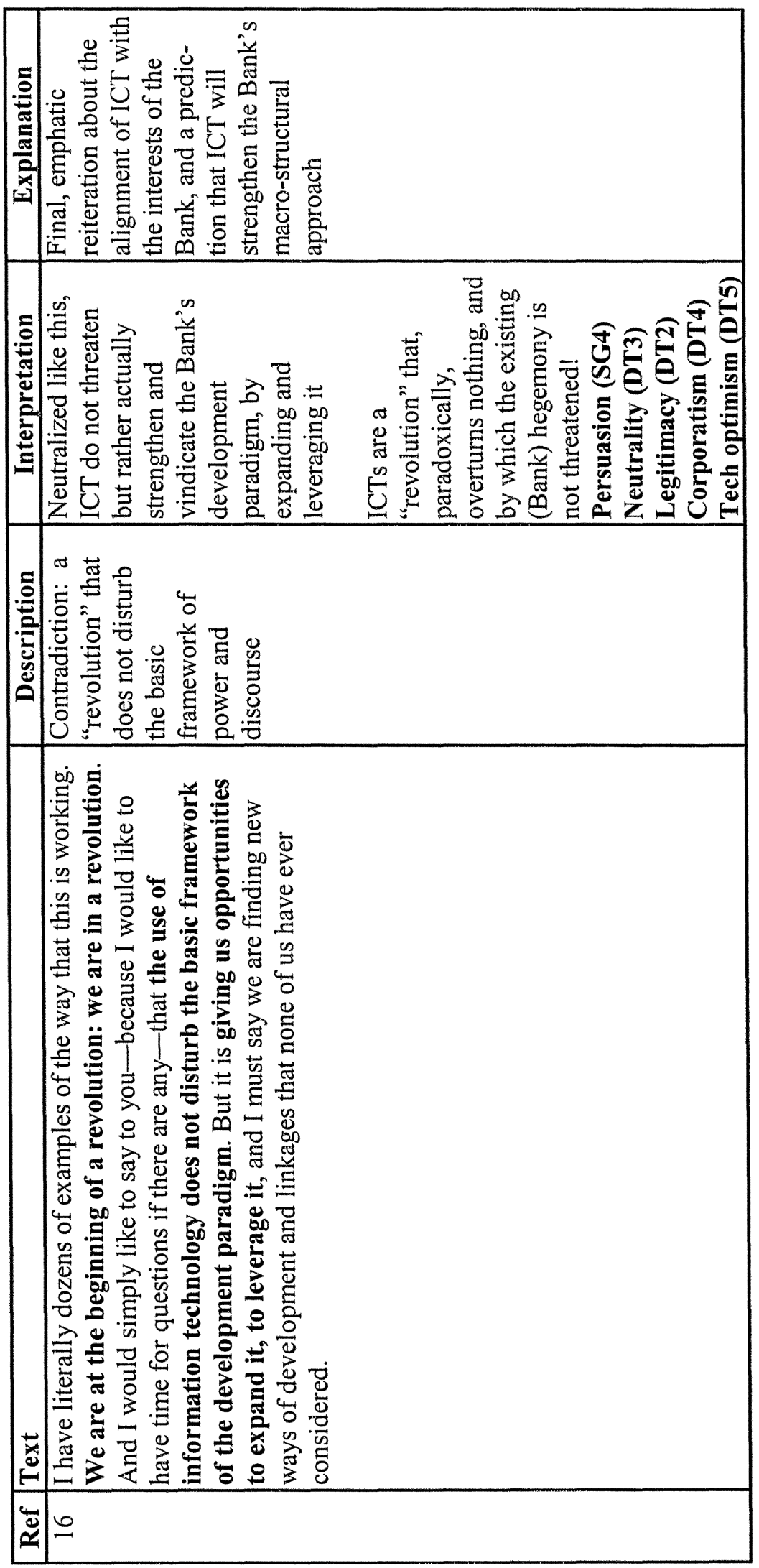


Thus in Ref 11 we can see ICT as a medium for transferring Western knowledge out (my term) to Africa, "from teaching sites in North America, French Canada and in Ireland"- - the inclusion of French Canada presumably in order to penetrate francophone Africa, an area otherwise less permeable to Western cultural transfer due to its general non-use of English. In Ref 12, the assumed neutrality (an important discursive type, or component, of developmental discourse) of such programs is demonstrated once again, where we are told that the "Virtual University of the Monterrey Tech System" is teaching " 300 towns in Latin America in seven countries...various subjects- from how to run a fire department to how to construct a budget... a Mayor in Costa Rica might be working with a Mayor in Mexico City" (Ref 12). However, this one-way flow of Western (sub)urban civic values and technical structure to the LDC context is not acknowledged; in fact, the actual phraseology used was "we link up...to teach." The separation of, and weakening of the association between, the subject and verb in this sentence is another masking device, where

The cumulative effect of the transformations is that the direct commander-commanded relationship has been changed into a relationship wherein the commander plays the role of an information giver and the commanded is assigned the role of an information receiver ( $\mathrm{Ng}$ and Bradac 1993, p. 163).

Such depoliticization of a problematic use of technology within development is also visible in Ref 13, where the ability of ICT-mediated satellite communication to normalize and control the speaking time of interactants around the world is presented unequivocally as a benefit for all.

Perhaps the most incongruous part of the speech, however, is Refs 14 and 15 , where the speaker relates how he was "literally in the jungle with no water, no power, rough streets, and where I was made a Chief....there is gold....I am sitting with my brother Chiefs and one of them - it is a brother chief not a sister chief I might tell you in most parts of Africa"(Ref 14). As discussed in Ref 2, the other markedly incongruous part of the speech, the speaker uses the speech genres of humor and confidence to overcome what is, in this case, a piece of blatant Orientalism:

Orientalism can be discussed and analyzed as the corporate institution for dealing with the Orient-dealing with it, by making statements about it, authorizing views of it, describing it, by teaching it, settling it, ruling over it: in short, Orientalism as a Western style for dominating, restructuring, and having authority over the Orient (Said 1978, p. 3). 
Although softened with the speech genres of humor and confidence, the other - in this case, the Orient - is being recreated in the present with every word of the text. Moreover, in the phrase "forwards, contracts-I mean more tough-minded traders you have never seen," it is implied that such "brother chiefs" are (presumably, contrary to indications otherwise) natural, toughminded traders just waiting to embrace the (natural) extension of international market capitalism into the "jungle" via ICT.

By Ref 16, the Bank's unproblematic approach to planning, deployment, and use of ICT within its own developmental paradigm has been replicated and normalized in front of our eyes. It remains only for the speaker to pull a final discursive conjuring trick:

We are at the beginning of a revolution: we are in a revolution. And I would simply like to say to you... that the use of information technology does not disturb the basic framework of the development paradigm (Ref 16).

A similar appropriation and use of discursive terms associated with a perceived threat has been noted by Chilton (1998), whose discourse analysis of the protracted confrontation between the government of Margaret Thatcher in the UK and the anti-nuclear peace movement of the 1980s highlights her statement that "we [the government] are the true peace movement" (Daily Telegraph April 29, 1983), and the invention of the phrase peacemongers to refer to CND (Campaign for Nuclear Disarmament) protesters. However, the speaker's own doublespeak in Ref 16, about a revolution which does not alter the basic framework of power, is followed by an almost sinister continuation, which summarizes in a phrase the deep and growing linkages between ICT, development discourse, and relations of power. The remark may not bode well for those who do not support their own objectification by the Bank as developing:

But it [information technology] is giving us opportunities to expand it [the development paradigm], to leverage it, and I must say we are finding new ways of development...that none of us have ever considered (Ref 16).

\section{CONCLUSION}

This paper has identified some of the major components of the World Bank's discourse surrounding ICT and development, and shown how the manner of their deployment in speech amounts to the creation and systematization of a 
set of discursive relations that support and extend a markedly North American worldview. These relations are a fusion of traditional developmental discourse - technocratic expertise (DT1), combined with poverty as an undisputable need for such expertise (DT2)-with more ICT-specific components, such as the assumption of ICT as a neutral force in development (DT3), the display of expertise in the corporate terms with which ICT is often surrounded and discussed (DT4), technological optimism bordering on determinism(DT5), and a show of ICT pragmatic use on the ground, thus ensuring results (DT6). CDA is, of course, unable to make pronouncements about the degree to which social actors are aware of their actions in replicating macro-structures at the micro-level. To claim that the speech analyzed here was a set of conscious, cumulative constructions on the part of the speaker would be to impute almost impossibly Machiavellian aims (and abilities) to a person who, it is likely, undertakes his job in good faith, unaware, for the most part, of the assumptions and positionality with which speeches such as this appear, upon closer analysis, to be drenched. As observers and interpreters of social life, matters regarding others' discursive intentionality are not empirically available to us, although the resulting discourse itself, recalling Escobar at the beginning of this paper, is more visible: the (re)establishment of a set of normative relations among a set of elements, institutions, and practices, and their systematization to form a whole.

Indeed, it is this very task-uncovering, problematizing, and raising our consciousness about contestable assumptions which have, through sheer use, become woven into the fabric of discursive interaction--at which CDA arguably excels. The submerged nature of many such assumptions merely makes such a task the more pressing. That it is an important task is evidenced by the analysis itself: the links posited between discursive forms at the micro-level and the replication, or alteration, of discursive power relations at the macro-level that appear in the tables of the analysis in this paper. These links are able to show how local-level utterances are in fact saturated with prior assumptions about role, legitimacy, and the nature of the world - in short, about power - and how the inequalities attendant upon such assumptions can be reproduced, wittingly or unwittingly, in discursive practice.

This paper has shown how the appropriation and discursive deployment of ICT, with its association with progress and rationality, offers a powerful opportunity to further the interests of technocratic, often mainstream stakeholders, acting as a magnifier for dominant discursive interests by creating new subjects for objectification. The ability of CDA to expose this effect, identify the various elements of such discourse in practice, and show how their interaction is systematized into a "technology of representation" (Foucault 1975, p. 104), thus renders it a useful tool for IS researchers; in particular, those wishing to understand the potent interaction of ICT with developmental and other 
discursive gazes that look out upon contested organizational landscapes. Thus CDA might prove an appropriate framework for the analysis of discourse within the more mainstream IS study domains of, say, IS strategy, IS procurement, compilation of requirements catalogues, discussions about hardware relocation, budget allocation, process redesign, iterative prototyping, program review boards - anywhere at all, in fact, where the prevailing discourse masks submerged assumptions and interests regarding the nature and role of ICT.

\section{REFERENCES}

Aslam, A. "World Bank Accused of 'Fraud' in Internet Scheme," Jubilee 2000 UK, http://www.jubilee2000uk.org/worldnews/northamerica/WB_fraud_internet.htm, 2001.

Avgerou, C. "The Multiple Rationalities of Information Systems Deployment," Proceedings of IFIP WG9.4 Conference 2000: Information Flows, Local Improvizations and Work Practices, Cape Town, May 24-26, 2000.

Avgerou, C., and Walsham, G. (Eds.). Information Technology in Context. Aldershot, UK: Ashgate Publishing, 2000.

Bhatnagar, S. "Social Implications of Information and Communication Technology in Developing Countries: Lessons from Asian Success Stories," Electronic Journal on Information Systems in Developing Countries (1), 2000, http://www.is.cityu.edu. hk/research/ejisdc/vol1/vl r4.pdf.

Bloomfield, B., and Coombs, R. "Information Technology, Control, and Power: The Centralization and Decentralization Debate Revisited," Journal of Management Studies (29:4), 1992, pp. 459-484.

Castells, M. "A Rejoinder: On Power, Identities and Culture in the Network Society," New Political Economy (3:3), 1998, pp. 473-483.

Castells, M. The Information Age: Economy, Society and Culture. Oxford: Blackwell, 1997.

Chambers, R., Pacey, A., and Thrupp, L. Farmer First. London: Intermediate Technology Publications, 1989.

Chilton, P. Language and the Nuclear Arms Debate: Nukespeak Today. London: Frances Pinter, 1988.

Dahl, G., and Hjort, A. "Development as Message and Meaning," Ethnos (34), 1984, pp. 165-185.

Danowitz, A.K., Nassef, Y., and Goodman, S.E. "Cyberspace Across the Sahara: Computing in North Africa," Communications of the ACM (38:12), 1995, pp. 23-28.

Escobar, A. Encountering Development: The Making and Unmaking of the Third World. Princeton, NJ: Princeton University Press, 1995.

Fairclough, N. Critical Discourse Analysis: The Critical Study of Language. London: Longman, 1995a.

Fairclough, N. "Linguistic and Intertextual Analysis within Discourse Analysis," in A. Jaworski and N. Coupland (eds.), The Discourse Reader. London: Routledge, 1999.

Fairclough, N. Media Discourse, London: Edward Arnold, 1995b.

Foucault, M. The Archaeology of Knowledge and the Discourse on Language, trans. A. M. Sheridan. London: Tavistock, 1972.

Foucault, M. Discipline and Punish. London: Penguin, 1975.

Gardner, K., and Lewis, D. J. Anthropology, Development and the Post-Modern Challenge. Chicago: Pluto Press, 1996.

Gillespie, A., and Cornford, J. "Telecommunication Infrastructures and Regional Development," in W. H. Dutton (ed.), Information and Communication Technologies: Visions and Realities. Oxford: Oxford University Press, 1997, pp. 335-351. 
Goffman, E. Forms of Talk. Philadelphia: University of Pennsylvania Press, 1981.

Grint, K., and Woolgar, S. The Machine at Work: Technology, Work and Organization. Cambridge, MA: Polity Press, 1997.

Hobart, M. (Ed.). An Anthropological Critique of Development: The Growth of Ignorance. London: Routledge, 1993.

Holland, D., Lachincotte, W., Skinner, D., and Cain, C. Identity and Agency in Cultural Worlds. Cambridge, MA: Harvard University Press, 1998.

Jensen, M. The African Internet-A Status Report. http://demiurge.wn.apc.org/ africa/afstat.htm, 2001.

Long, N., and Long, A. Battlefields of Knowledge: The Interlocking of Theory and Practice in Social Research and Development. London: Routledge, 1992.

Mohan, G. "Developing Differences: Post-Structuralism and Political Economy in Contemporary Development Studies," Review of African Political Economy (73), 1997, pp. 311-328.

$\mathrm{Ng}$, S., and Bradac, J. Power in Language: Verbal Communication and Social Influence. London: Sage, 1993.

Orlikowski, W. "CASE Tools as Organizational Change: Investigating Incremental and Radical Changes in Systems Development," MIS Quarterly (17:3), 1993, pp. 309-340.

Perez, C. "New Technologies and Development," in C. Freeman and B. Lundvall (eds.), Small Countries Facing the Technological Revolution. London: Continuum International Publishing, 1988.

Pottier, J. (Ed.). Practicing Development: Social Science Perspectives. London: Routledge, 1993.

Rojo, L., and van Dijk, T. "There Was a Problem, and It Was Solved!: Legitimating the Expulsion of 'Illegal' Migrants in Spanish Parliamentary Discourse," Discourse and Society (8:4), 1997, pp. 523-566.

Sachs, W. (Ed.). The Development Dictionary: A Guide to Knowledge as Power. London: Zed Books, 1992.

Said, E. W. Orientalism. London: Penguin Books, 1978.

Sen, A. Development as Freedom. Oxford: Oxford University Press, 1999.

Smithson, S., and Land, F. "Information Systems Education for Development," Information Technology for Development, (1:2), 1986.

Titscher, S., Meyer, M., Wodak, R., and Vetter, E. Methods of Text and Discourse Analysis, trans. B. Jenner. London: Sage, 2000.

UNCTAD (United Nations Conference on Trade and Development). "Review of the Activities of the United Nations System in the Area of Information Technology and Development," paper prepared for the United Nations Commission in Science and Technology for Development, Geneva, January 1997.

UNESCO (United Nations Educational, Scientific, and Cultural Organization). "Information and Communication Technologies in Development: A UNESCO Perspective," report prepared by the UNESCO Secretariat, CII-96/WS/6, Paris: Unesco, 1996.

Van Dijk, T. (Ed). Handbook of Discourse Analysis (Volumes 1-3). London: Academic Press, 1985.

Van Maanen, J., and Barley, S. "Cultural Organization: Fragments of a Theory," in P. Frost, L. Moore, M. Louis, C. Lundberg, and J. Martin (eds.), Organizational Culture. Beverly Hills, CA: Sage, 1985.

Wilks, A. A Tower of Babel on the Internet? The World Bank's Development Gateway. Infoterra, http://www.cedar.at/mailarchives/infoterra/2001/msg00588.html, 2001.

Wilson, J. Politically Speaking: The Pragmatic Analysis of Political Language. Oxford: Blackwell, 1990. 


\begin{abstract}
About the Author
Mark Thompson recently completed a Ph.D. (2002) at the Judge Institute of Management, Cambridge University, examining the impact of sociological theories of practice, or emergent ontologies, for conceptions of the role of the self in IS and organizational studies and its implications for future research within both genres. His primary fieldwork involved action research with health information systems in townships in Cape Town, South Africa (Information and Organization (12:3), 2002, pp. 183-211). Mark is currently a director of Methods Application Ltd, a London-based IS consultancy specializing in the management of major organizational IS change programs. Mark can be reached by e-mail atmpat2@cam.ac.uk.
\end{abstract}

